\title{
LAPORAN ANALISIS AIR, BANJIR, SERTA PERSPEKTIF MASAYARAKAT DI DESA PANTAI HAMBAWANG KECAMATAN MANDASTANA
}

Disusun untuk memenuhi tugas mata kuliah: Praktik Kerja Lapangan (PKL) Dosen Pengampu: Prof. Dr. Ersis Warmansyah Abbas, M.Pd

Prom. Dr. Bambang Subiyakto, M.Hum

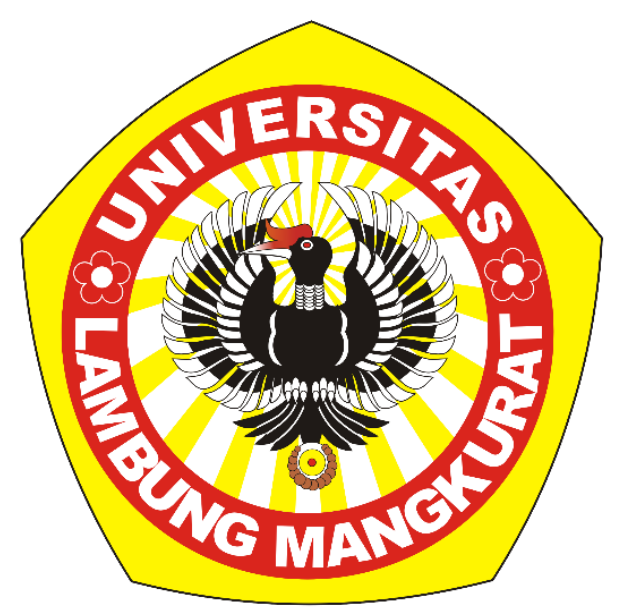

Oleh:

Muhammad Sahlan (1810128210012)

PROGRAM STUDI PENDIDIKAN ILMU PENGETAHUAN SOSIAL FAKULTAS KEGURUAN DAN ILMU PENDIDIKAN

UNIVERSITAS LAMBUNG MANGKURAT

FEBRUARI

2021 


\section{KATA PENGANTAR}

Puji syukur penulis panjatkan kehadirat tuhan yang maha esa yang telah memberikan limpahan rahmat, hidayah, serta inayah nya. Sehingga penulis dapat Menyusun laporan ini yang berjudul "LAPORAN ANALISIS AIR, BANJIR, SERTA PERSPEKTIF MASAYARAKAT DI DESA PANTAI HAMBAWANG KECAMATAN MANDASTANA”.

Laporan ini disusun untuk menambah pengetahuan kita mengenai terkait dengan momen yang beberapa saat lalu kita rasakan yaitu terkait dengan bencana banjir yang terjadi di Kalimantan selatan, khusu nya di desa pantai hambawang yang terletak di kecamatan mandastana, kabupaten barito kuala. Laporan ini juga disusun untuk memenuhi syarat mata kuliah Bimbingan Karya Ilmiah.

Laporan ini tersaji dengan disertai bantuan dari berbagai pihak, baik yang terlibat langsung maupun yang tidak terlibat secara langsung. Maka tidak lupa pula penulis ucapkan terimakasih kepada seluruh pihak yang sudah membantu menyelesaikan pembuatan laporan ini.

Dalam penyusunan laporan ini penulis menyadari masih banyak kesalahan dan kekurangan, oleh sebab itu penulis mengharapkan saran dan kritik yang bersifat membangun dan dapat dijadikan bahan koreksi untuk memperbaiki penyusunan laporan berikutnya.

Semoga laporan ini dapat bermanfaat khusunya bagi penulis dan umumnya bagi para pembaca laporan ini.

Penulis. 


\begin{abstract}
Abstrak
Artikel ini ditujukan kepada pembaca yang ingin mengetahui terkait dengan banjir, khusus nya musibah banjir yang terjadi di desa pantai hambawang, kecamatan mandastana, kabupaten barito kuala, Kalimantan selatan. Musibah banjir tersebut berlangsung terjadi selama 1 bulan lebih terhitung mulai terendam nya pemukiman warga setempat. Banjir tersebut banyak mengakibatkan kerurugian besar terhadap warga yang berada di wilayah tersebut, baik dalam hal ekonomi, infrastruktur, dan lain sebainya.

Bencana banjir, menduduki urutan ketiga penyebab kerugian ekonomi dari semua bencana alam di seluruh dunia. Semarang, sebagai kota waterfront telah menderita banjir sejak saat lama. Penelitian ini difokuskan untuk mengidentifikasi dan menganalisis respon masyarakat dan hubungannya dengan pengetahuan mereka, kesiapan dan tingkat tindakan.

Banjir sendiri secara umum dapat di definisikan sebagai suatu bencana alam, yang menimpa kehidupan warga yang bersangkutan dan dapat mengalami dampak negative serta menimbulkan kerugian materi. Bencana menurut Undang-undang No.24 Tahun 2007, yaitu peristiwa yang mengancam dan mengganggu kehidupan serta penghidupan masyarakat. Bencana dapat disebabkan baik oleh faktor alam dan faktor non alam (kegiatan manusia) sehingga mengakibatkan timbulnya korban jiwa, kerusakan lingkungan, kerugian harta benda, dan dampak psikologis.
\end{abstract}

Kata kunci: Banjir, sungai, dampak, 
KATA PENGANTAR ....................................................... II

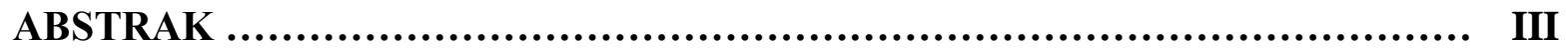

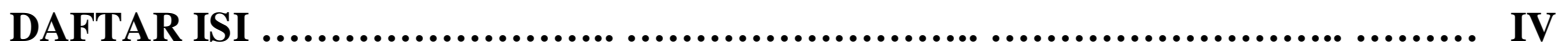

\section{BAB I PENDAHULUAN}
A. Latar belakang
1
B. Rumusan masalah ........................................................ 2

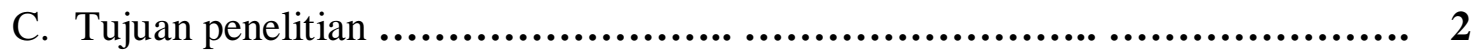

\section{BAB II PEMBAHASAN}
A. Mengenal apa itu banjir, faktor yang mempengaruhi terjadinya, serta dampak yang ditimbulkan Ketika dan pasca banjir. 3
B. Kondisi masyarakat di desa tersebut baik Ketika maupun pasca banjir .......... 5
C. Upaya yang dilakukan pemerintah/ penduduk setempat guna menghadapi banjir ... 6

\section{BAB III PENUTUP}
A. Keaimpulan
B. Daftar Pustaka 8 


\section{BAB I}

\section{PENDAHULUAN}

\section{A. Latar Belakang}

Terdapat 13 negara yang terletak di garis khatulistiwa, salah satunya adalah negara kita, Indonesia. Di Indonesia ada 8 provinsi yang dilalui garis khatulistiwa yaitu Sumatera Barat, Riau, Kalimantan Barat, Kalimantan Tengah, Maluku, dan Papua. Maka dari itu Indonesia sering mendapatkan bencana alam karena banyak hal, tidak terkecuali bencana banjir, banjir biasa nya disebabkan oleh curah hujan yang sangat tinggi disertai daerah resapan tanah yang kurang memadai akan genangan air.

Banjir merupakan suatu masalah yang sampai saat masih perlu adanya penanganan khusus dari berbagai pihak, baik dari pemerintah maupun masyarakat. Banjir bukan masalah yang ringan. Banjir dapat terjadi akibat naiknya permukaan air lantaran curah hujan yang diatas normal, perubahan suhu, tanggul/ bendungan yang bobol, pencairan salju yang cepat, terhambatnya aliran air di tempat lain (Ligal, 2008). Sedikitnya ada lima faktor penting penyebab banjir di Indonesia yaitu faktor hujan, faktor hancurnya retensi Daerah Aliran Sungai (DAS), faktor kesalahan perencanaan pembangunan alur sungai, faktor pendangkalan sungai dan faktor kesalahan tata wilayah dan pembangunan sarana dan prasarana.

Maka disini penulis hadir untuk mengetahui seberapa sering banjir datang di desa pantai hambawang ini dan seberapa baik tanah untuk resapan air di daerah tersebut. Serta apa saja dampak yang terjadi Ketika terjadi banjir di daerah tersebut baik dari presepsi masyarakat maupun pandangan pemerintah daerah setempat. 
B. Rumusan Masalah

1. Mengenal apa itu banjir, faktor yang mempengaruhi terjadinya, serta dampak yang ditimbulkan Ketika dan pasca banjir.

2. Bagaimana kondisi ekonomi masyarakat di desa tersebut baik Ketika maupun pasca banjir

3. Apa saja upaya yang telah dilakukan pemerintah atau penduduk setempat guna menghadapi banjir

C. Tujuan penelitian

Dari rumusan masalah di atas dapat di Tarik tujuan penelitian ini diantara nya untuk:

1. Untuk Mengenal apa itu banjir, faktor yang mempengaruhi terjadinya, serta dampak yang ditimbulkan Ketika dan pasca banjir.

2. Untuk mengetahui Bagaimana kondisi ekonomi masyarakat di desa tersebut baik Ketika maupun pasca banjir

3. Untuk mengetahui Apa saja upaya yang telah dilakukan pemerintah atau penduduk setempat guna menghadapi banjir 


\section{BAB II}

\section{PEMBAHASAN}

A. Mengenal apa itu banjir, faktor yang mempengaruhi terjadinya, serta dampak yang ditimbulkan Ketika dan pasca banjir.

Jika dicermati, bencana alam di Indonesia tampaknya dari tahun ke tahun memiliki kecenderungan meningkat, begitu juga bencana banjir yang setiap tahun terjadi di seluruh penjuru tanah air. Kecenderungan meningkatnya bencana banjir di Indonesia tidak hanya luasnya saja melainkan kerugiannya juga ikut bertambah pula.

1. Mengenal banjir

Definisi banjir menurut Multilingual Technical Dictionary on Irrigation and Drainage, ICID (dalam Siswoko, 2002) adalah :. a relatively high flow or stage in a river, markedly higher than the usual; also the inundation of low land that may result therefrom. A body of water, rising, swelling and overflowing the land not usually thus covered. Sedikitnya ada lima faktor penting penyebab banjir di Indonesia yaitu ; faktor hujan, faktor hancurnya retensi Daerah Aliran Sungai (DAS), faktor kesalahan perencanaan pembangunan alur sungai, faktor pendangkalan sungai dan faktor kesalahan tata wilayah dan pembangunan sarana dan prasarana (Agus Maryono, 2005).

Sedangkan definisi banjir secara umuum adalah suatu kenaikan debit air sehingga dapat menggenangi suatu daerah yang dampak nya dapat merugikan masyarakat sekitar hingga dapat memetikan perekonomian masyarakat sekitar.

Pratomo, A. J. (2008). Analisis Kerentanan Banjir di Daerah Aliran Sungai Sengkarang Kabupaten Pekalongan Provinsi Jawa Tengah dengan Bantuan Sistem Informasi Geografis (Doctoral dissertation, Universitas Muhammadiyah Surakarta).

2. Factor yang menyebabkan banjir

Bencana banji yang melanda masyarakat memiliiki factor yang dapat menimbilkan adanya bencana banjir, diantara nya adalah:

a. Faktor Kondisi Drainase yang Tidak Memadai

Kondisi tidak memadainya infrastruktur tersebut secara umum dikarenakan banyak saluran drainase di wilayah Kecamatan Manggala yang belum terbangun.

Kondisi tersebut semakin diperparah dengan permasalahan interkoneksi saluran baik yang disebabkan oleh sedimentasi yang tinggi, ataupun dampak 
pembangunan. Hal tersebut menyebabkan pendangkalan drainase yang berakibat kepada penurunan kapasitas sistem drainase, sehingga tidak mampu mengendalikan limpasan air permukaan dari hujan ataupun limpasan berupa banjir kiriman

b. Faktor Lokasi Permukiman berada di Daerah Akumulasi Genangan (Cekungan dan Landai)

Faktor lokasi permukiman berada di daerah akumulasi genangan yaitu cekungan dan landai menjelaskan mengenai banyak permukiman masyarakat yang terbangun di wilayah beresiko terdampak banjir seperti di daerah cekungan dan di daerah landai.

c. Faktor Penurunan Daya Infiltrasi Tanah

Pengaruh kepadatan bangunan yang cenderung mengalami peningkatan akibat penetapan kawasan sebagai kawasan permukiman terpadu, berdampak kepada masyarakat dan lingkungan. Pertumbuhan pembangunan yang sangat tinggi mendesak keberadaan sungai dan saluran drainase, dan daerah resapan air menjadi semakin kecil. Sehingga berdampak pada daya resap air yang rendah, akibat tutupan lahan akan perkerasan semakin luas.

Rachmat, A. R., \& Pamungkas, A. (2014). Faktor-Faktor kerentanan yang berpengaruh terhadap bencana banjir di Kecamatan Manggala Kota Makassar. Jurnal Teknik ITS, 3(2), C178-C183.

3. dampak yang ditimbulkan Ketika dan pasca banjir

dampak yang ditimbulkan sangat bervariasi, tertgantung wilayah yang terdampak banjir. Namun begitu dapat di ambil secara umum dampak banjir yang di timbulkan, diantara nya adalah:

a. matinya perekonomian masyarakat setempat,

b. lumpuhnya alat transportasi darat

c. terhambat nya aktivitas masyarakat

d. serta dapat menimbulkan penyakit (jika air yang tergenang adalah air yang bercampur dengan sampah)

Marfai, M. A., \& Cahyadi, A. (2017). Dampak bencana banjir pesisir dan adaptasi masyarakat terhadapnya di kabupaten Pekalongan. 
B. Kondisi masyarakat di desa tersebut baik Ketika maupun pasca banjir

Banjir dapat terjadi akibat naiknya permukaan air lantaran curah hujan yang diatas normal, perubahan suhu, tanggul/ bendungan yang bobol, pencairan salju yang cepat, terhambatnya aliran air di tempat lain Bencana banjir sering menimbulkan dampak negative terhadap wilayah yang digenangi nya, baik secara finansisal maupun secara aktivitas masyarakat. Namun menurut saya pribadi sebagai masyarakat yang juga terdampak banjir di perkampungan, bahwa banjir tidak sepenuhnya membawa dampak buruk bagi kehidupan, diantara dampak buruk yang dibawa bencana banjir terdapat pula dampak baik yang dibawa oleh bencana banjir. Dianta dampak baik dan dampak buruk nya dapat kita uraikan dibawah ini, diantaranya adalah:

1. Dampak negatiif

Dampak negative yang dirasakan oleh masyarakat desa pantai hambawang sanagat bervariasi, mulai dari keterhambtan aktivitas rutin, hingga lumpuhnya perekonomian masyarakat sekitar. Keterhambatan aktivitas masyarakat rutin yang terjadi menurut ibu Bariyah yang saya wawancarai selaku warga yang terdampak bencana banjir adalah suami nya yang juga bekerja sebagai buruh bangunan menjadi terhambat dalam pekerjaan beliau dikarenakan akses transportasi darat yang lumpuh total dan hanya bisa dilalui oleh kapal (transportasi air) otomatis hal itu akan lebih memakan waktu.

Sedangkan contoh lumpuhnya perekonomian masyarakat sekitar menurut bapak Arul yang juga selaku warga yang terdampak banjir adalah yang biasa nya beliau bekerja berjualan baju di pasar, maka selama banjir beliau hanya berjaga dirumah, dan tidak mendapat pemasukan sama sekali. Beliau adalah juga seorang petani, dimana beliau turut merasakan hal negative yang terjadi. Dimana dalam sector pertanian juga lumpuh total.

Selain itu juga dampak negative yang terjadi menurut kepala desa pantai hambawang bapak Mahdianoor, adalah lepas nya binatang liar dari penangkaran. Dikabarkan bahwa di desa tersebut sempat terlihat 3 ekor buaya yang lepas dari penangkaran yang berada tidak jauh dari desa pantai hambawang, atau bisa dikatakan bahwa penangkaran tersebut berada di desa tetangga dari desa pantai hambawang, jelasnya.

2. Dampak Positif

Menurut satu di antara tetua adat di desa pantai hambawang bapak H. Marno mengatakan bahwa bencana banjir ini tidak sepenuhnya membawa dampak buruk bagi kehidupan masyarakat. Menurut pria berusia hampir 50 tahun itu bencana ini juga mendatangkan hal positif, dimana menurut beliau dengan terjadinya bencana banjir ini 
ada beberapa jenis ikan payau yang masuk kepedesaan tersebut seperti lele dumbo, dan ikan Nila. Beliau menuturkan bahwa pada sebelum banjir kondisi air di desa tersebut sangat "kalat" (sebutan orang banjar pada kondisi air yang terasa kecut) maka dengan dating nya banjir kondisi air di desa tersebut menjadi hambar/menjadi air payau.

C. Upaya yang dilakukan pemerintah/ penduduk setempat guna menghadapi banjir

Dalam hal ini pmerintah bukan hanya diam saja, namun pemerintah daerah juga sudah mempersiapkan hal-hal yang berkemungkinan terjadi saat akan dating bencana banjir, salah satu nya adlah pengerukan kembali sungai inti yang terdapat di desa pantai hambawang, namun keadaan berbicara lain. Banjir tetap melanda desa itu, dikarenakan curah dan intensitas hujan yang cukup tinggi, sehingga bendungan di daerah riam kanan tidak dapat lagi menanggung beban yang cukup berat tersebut sehingga mengakibatkan banjir di seluruh Kalimantan selatan dan tidak terkecuali desa pantai hambawang yang berada di kecamatan mandastana kabupaten barito kuala.

Sedangkan upaya yang dilakukan oleh masyarakat sekitar hanya dilakukan Ketika banjir telah merendam desa. Mereka hanya mengupayakan bahwa harta bendayang mereka miliki agar tidak tersentuh air yang terus naik, khusus nya padi.

Bapak ramlianoor selaku ketua RT 03 di desa pantai hambawang tersesbut mengatakan bahwa warga hanya bisa bertahan dirumah dan menyelamatkan harta benda mereka terutama padi yang menjadi penghasilan uutama mereka di desa pantai hambawang. 


\section{BAB III}

PENUTUP

\section{A. Kesimpulan}

Factor yang menyebabkan banjir Bencana banji yang melanda masyarakat memiliiki factor yang dapat menimbilkan adanya bencana banjir, diantara nya adalah Faktor Kondisi Drainase yang Tidak Memadai dan Faktor Lokasi Permukiman berada di Daerah Akumulasi Genangan (Cekungan dan Landai) Faktor lokasi permukiman berada di daerah akumulasi genangan yaitu cekungan dan landai beresiko terdampak banjir seperti di daerah cekungan dan di daerah landai.

Namun begitu dapat di ambil secara umum dampak banjir yang di timbulkan, diantara nya adalah matinya perekonomian masyarakat setempat, lumpuhnya alat transportasi darat, terhambat nya aktivitas masyarakat, serta dapat menimbulkan penyakit (jika air yang tergenang adalah air yang bercampur dengan sampah)

Kondisi masyarakat di desa tersebut baik Ketika maupun pasca banjir Banjir dapat terjadi akibat naiknya permukaan air lantaran curah hujan yang diatas normal, perubahan suhu, tanggul/ bendungan yang bobol, pencairan salju yang cepat, terhambatnya aliran air di tempat lain Bencana banjir sering menimbulkan dampak negative terhadap wilayah yang digenangi nya, baik secara finansisal maupun secara aktivitas masyarakat.

Namun menurut saya pribadi sebagai masyarakat yang juga terdampak banjir di perkampungan, bahwa banjir tidak sepenuhnya membawa dampak buruk bagi kehidupan, diantara dampak buruk yang dibawa bencana banjir terdapat pula dampak baik yang dibawa oleh bencana banjir. 
B. Daftar Pustaka

Pratomo, A. J. (2008). Analisis Kerentanan Banjir di Daerah Aliran Sungai Sengkarang Kabupaten Pekalongan Provinsi Jawa Tengah dengan Bantuan Sistem Informasi Geografis (Doctoral dissertation, Universitas Muhammadiyah Surakarta).

Rachmat, A. R., \& Pamungkas, A. (2014). Faktor-Faktor kerentanan yang berpengaruh terhadap bencana banjir di Kecamatan Manggala Kota Makassar. Jurnal Teknik ITS, 3(2), C178-C183.

Marfai, M. A., \& Cahyadi, A. (2017). Dampak bencana banjir pesisir dan adaptasi masyarakat terhadapnya di kabupaten Pekalongan.

Deasy, A. (2017). Dampak Bencana Banjir Terhadap Kondisi Sosial Ekonomi masyarakat di Kecamatan Batu Benawa Kabupaten Hulu Sungai Tengah, Kalimantan Selatan. JPG (Jurnal Pendidikan Geografi), 4(4), 42-52.

Subiyakto, B., \& Abbas, E. W. (2020). Strategi Pembelajaran IPS: Konsep dan Aplikasi.

Findayani, A. (2018). Kesiap siagaan masyarakat dalam penanggulangan banjir di Kota Semarang. Jurnal Geografi: Media Informasi Pengembangan dan Profesi Kegeografian, 12(1), 102-114.

Subiyakto, B., Mutiani, M., \& Hidayat Putra, M. A. (2019). Laporan Penelitian: Pergeseran Makna Klotok Bagi Masyarakat di Aliran Sungai Martapura.

ABBAS, E. W., Hidayat Putra, M. A., \& Noor Handy, M. R. (2019). Laporan Penelitian: PEMANFAATAN EKOWISATA SUNGAI MARTAPURA KOTA BANJARMASIN SEBAGAI SUMBER BELAJAR IPS. 
Subiyakto, B. (2005). Arti Penting Perairan Bagi Transportasi Masyarakat Banjar. Jurnal Kandil, 9.

Subiyakto, B. (2005). Menjadikan Sungai Sebagai Objek Studi. Jurnal Kandil Edisi Tahun III Mei-Juli.

Subiyakto, B., Abbas, E. W., Arisanty, D., Mutiani, M., \& Akmal, H. (2020). Sungai dan Kehidupan Masyarakat Banjar: Penguatan Lokalitas dalam Wacana Pendidikan IPS yang Responsif. 